\title{
Seroprevalence of HBV, HCV and HIV co-infection in selected individuals from state of São Paulo, Brazil
}

\author{
Alexandre Martins Portelinha Filho', Charles Ulloffo do Nascimento', \\ Talita Nicastro Tannourii', Charlene Troiani ${ }^{2}$, Eloah Lopes Ascêncio ${ }^{2}$, Renata Bonfim³ \\ Lourdes Aparecida Zampieri D'Andrea ${ }^{3}$, Luiz Euribel Prestes-Carneiro'²/+
}

\footnotetext{
'Departamento de Doenças Infecciosas, Hospital Universitário ²Departamento de Imunologia, Universidade do Oeste Paulista, Rua José Bongiovani 700, 19050-680 Presidente Prudente, SP, Brasil Instituto Adolfo Lutz, Presidente Prudente, SP, Brasil
}

\begin{abstract}
Few studies are available on hepatitis B virus (HBV), hepatitis $C$ virus (HCV) and human immunodeficiency virus (HIV) co-infection in populations living in small and medium-sized Brazilian cities. We evaluated the seroprevalence of these viruses in selected individuals from a clinic of infectology, who were referred to the University Regional Hospital of the West Region of state of São Paulo, Brazil. Among a total of 7,021 individuals seen in the clinic following receipt of preliminary ELISA results or having the suggested clinical signs of viral hepatitis or HIV, 1,228 were systematically screened. Isolated or associated HBSAg, HCV and HIV antibodies were found in $44.9 \%$ of the subjects. Anti-HIV antibodies were found in $24.7 \%$ of the patients, $20.3 \%$ of whom had an HIV monoinfection and $4.4 \%$ of whom were co-infected with hepatitis viruses (HCV: 4\%; HBV: 0.4\%). Anti-HCV antibodies were found in $14 \%$ of the patients and $5.9 \%$ had anti-HBsAg antibodies. HCV infection affected males more than females $(p<0.05)$ and individuals $>50$-years old had an increased prevalence of anti-HCV compared to HIV ( $p=0.0001)$ or HBV ( $p=0.0063)$. HCV-RNA was detected in $73.5 \%$ of the samples with a predominance of genotype $1(72.5 \%)$. A significant percentage (44.9\%) of the selected individuals was positive for antibodies against HBV, HCV and/or HIV; these patients would otherwise have remained undiagnosed.
\end{abstract}

Key words: hepatitis B virus - hepatitis C virus - human immunodeficiency virus co-infection - HCV genotypes seroprevalence - São Paulo

In Latin America, there are approximately 1.6 million individuals living with human immunodeficiency virus co-infection (HIV). In 2007, 100,000 newly infected individuals were diagnosed and 58,000 died of HIV (Kallings 2008). Although the incidence rates have declined since 2002, the Brazilian population contains one-third of all people living with HIV in Latin America (UNAIDS 2008). In addition to HIV-infection, viral hepatitis has also become an important public health problem worldwide. Although hepatitis B virus (HBV) infection can be prevented by vaccination, it remains endemic in various regions of the world, with areas of low $(<2 \%)$, medium $(2-7 \%)$ and high prevalence. Current studies indicate that 170 million people worldwide are infected by the hepatitis $\mathrm{C}$ virus (HCV). In developing countries, the infection is aggravated by difficulties in diagnosis and the high cost of anti-hepatitis drugs. Since HIV, HBV and HCV share similar routes of transmission, HIV co-infection with HBV or HCV is common (Soriano et al. 2006, Alter 2007, Lazarus et al. 2007).

The nationwide epidemiological situation for HBV, $\mathrm{HCV}$ and HIV infections is difficult to quantify due

\footnotetext{
Financial support: CCPq-Unoeste, Instituto Adolfo Lutz

+Corresponding author: luiz@unoeste.br

Received 11 March 2009

Accepted 2 September 2009
}

to local and regional characteristics as well as the high number of asymptomatic infections (Tavares-Neto et al. 2004, Silva et al. 2006). Furthermore, most Brazilian studies, particularly ones dealing with hepatitis, were carried out in selected populations (e.g., prisoners, individuals with renal failure undergoing hemodialysis, intravenous injection drug users and health care workers) (Paraná et al. 2007, Fialho et al. 2008, Oliveira et al. 2009). Patients attending a given clinic of infectology at a regional hospital also represent a specific risk group, as a wide variety of infectious diseases are screened. However, these patients offer an opportunity to specifically select individuals considered at risk for blood-borne diseases. Moreover, few studies address the epidemiologic futures of populations living in small and medium-sized cities in Brazil. Our aim was to evaluate the seroprevalences of HBV (anti-HBsAg), HCV (anti$\mathrm{HCV}$ ) and HIV-hepatitis virus co-infection (anti-HIV) in individuals selected from the infectology clinic at the regional University Hospital.

\section{PATIENTS, MATERIALS AND METHODS}

Study design - Located in the western part of Southeast Brazil, the Pontal of Paranapanema is considered to be one of the poorest regions of state of São Paulo (SP). It is composed of 32 municipalities with approximately 680,000 inhabitants who mainly live in small cities and rural communities. This is a descriptive and retrospective study that analyzed the files of individuals referred to the regional reference clinic of 
infectology at the Regional University Hospital Dr. Domingos Leonardo Cerávolo (UH) located in Presidente Prudente city, SP, Brazil. From January 2000-December 2006, 7,021 subjects carrying a Reference Guide of the Health Secretary of the state of São Paulo were referred to the UH clinic of infectology. Approximately $50 \%$ of the guides were referred by primary health care centres distributed in the municipalities of the XI Regional Health Secretary of Presidente Prudente-SP and $30 \%$ of the patients were referred by the clinics of different $\mathrm{UH}$ specialists - $15 \%$ by the UH Emergency Centre and 15\% by blood banks of the region. A total of 7,021 patients were seen during this period. Out of those, 1,228 patients were systematically selected for HBV (HBsAg), HCV (anti-HCV) and HIV (anti-HIV) serological screening based on preliminary serological results (positive ELISA results for $\mathrm{HBsAg}, \mathrm{HCV}$ and $\mathrm{HIV}$ ) or suggestive clinic evaluations for viral hepatitis or HIV. Serum samples were analysed by ELISA using a third generation test. Individuals with anti-HIV antibodies had their diagnoses confirmed by western blot or indirect immunofluorescence assay and viral load counts.

Molecular assays - Since 2002, individuals with anti-HCV antibodies have been tested by RNA-PCR and genotyping at the Regional Unit of the Adolfo Lutz Institute, Presidente Prudente, SP, Brazil. Only subjects who were seropositive for anti-HCV antibodies were screened for HCV-RNA. An Amplicor kit was used according to the manufacturer's instructions (COBAS AMPLICOR ${ }^{\mathrm{TM}}$ Hepatitis C Virus Test, version 2.0, Roche Diagnostics, Mannheim, Germany). HCV-RNA genotyping determination is clinically important to define the optimal duration and type of therapy to be used for treatment. RNA genotyping was conducted in samples positive for $\mathrm{HCV}$ RNA using the INNO-LiPA HCV II kit according to the manufacturer's instructions (Versant, Bayer Diagnostics, Tarrytown, NY, USA). The protocol for this study was approved by the Ethical Committee of Universidade do Oeste Paulista and Adolfo Lutz Institute, Presidente Prudente, SP, Brazil.

Statistical analysis - Fisher's exact test and the Chisquare test were used to analyse data via GraphPad Instat software (V4.0, San Diego, CA). All p values are twotailed; $p$ values $<0.05$ were considered to be statistically significant. Prevalence is defined as the ratio of the number of positive samples to the total number of tested samples.

\section{RESULTS}

Isolated or associated antibodies were found in $44.9 \%$ of individuals (552 of the 1,228). The overall seroprevalence of anti-HIV antibodies in the screened population was $24.7 \%$ (303 of 1,228$)$. Of the HIVpositive patients, $20.3 \%$ (249 of the 1,228) had an HIV monoinfection and $4.4 \%(54$ of 1,228$)$ were co-infected with hepatitis viruses: $4 \%(49$ of 1,228$)$ with $\mathrm{HCV}$ and $0.4 \%$ (5 of 1,228$)$ with HBV (Table I). Then, the results were stratified and only individuals with HIV were analysed, the co-infection rate was $16.1 \%$ for HIV-HCV (49/303), $1.6 \%$ for HIV-HBV (5/303) and $0.3 \%(1 / 303)$ for HIV-HBV-HCV (Table I).
The overall seroprevalence rate for $\mathrm{HCV}$ infection (anti-HCV) in the screened population was $14 \%$ $(173 / 1,228)$. There was an increase in the prevalence of anti-HCV antibodies in individuals $>50$-years old compared to HIV $(p=0.0001)$ or HBV $(p=0.0063)$ (Figure). However, for all viruses, there was a higher incidence of infected individuals aged 31-50 (Figure). HCV-RNA was detected in $73.5 \%(108 / 147)$ of the samples from subjects with anti-HCV antibodies. The HCV genotype was determined in $42.2 \%(62 / 147)$ of the individuals and there was a $72.6 \%$ predominance of genotype $1(45 / 62)$, while genotype 3 accounted for $24.2 \%$ (15/62) of the infected individuals. Mixed infections were found in $3.2 \%(2 / 62)$ of the patients and were associated with genotypes 1 and 2 (Table II).

The overall seroprevalence for HBV infection (anti-HBsAg) was 5.9\% $(73 / 1,228)$ (Table I). In general, infections were found in males more frequently than in females, with a ratio of 1.3:1 for HIV, 1.4:1 for HBV, 2.4:1 for $\mathrm{HCV}$ and 3:1 for $\mathrm{HIV} / \mathrm{HCV}$ co-infection $(\mathrm{p}<0.05)$ (Table I).

\section{DISCUSSION}

A significant percentage of seropositive patients $(44.9 \%)$ were found in screening tests for HBV, HCV and HIV-co-infection, thus highlighting the importance of regional hospitals in the diagnosis of populations considered at risk for blood-borne diseases. A possible explanation for these results is the considerable number of primary public health care centres distributed throughout the municipalities in our region. In these centres, doctors are directed to screen for HIV and viral hepatitis and to refer the patients to the regional UH.

It was initially feared that the AIDS epidemic would be severe in Latin American countries, especially in Brazil, due to its large size, unequal social classes and low levels of education (Kallings 2008). It is noteworthy to point out that the government has established and expanded a voluntary HIV screening program for all individuals and improved the subsequent management of HIV-positive subjects. In this context, reference regional hospitals fulfil a strategic importance in detecting, confirming and managing the treatment of the patients. It has been demonstrated worldwide that regions without such possibilities have patients with delayed diagnosis and treatment, thus worsening the progression of the disease (Wolls-Kaloustian \& Kimaiyo 2006, Loewenson 2007).

Anti-HIV antibodies were found in $24.7 \%$ of individuals. Of these individuals, $20.3 \%$ had an HIV monoinfection and $4.4 \%$ were co-infected with hepatitis viruses. These HIV rates are similar to infection among specific population subgroups in Brazil, such as $17 \%$ of prison inmates in São Paulo city (Coelho et al. 2007) and 20.6\% among intravenous injecting drug users in Porto Alegre city (Pechansky et al. 2006).

The prevalence of hepatitis virus co-infection in the HIV-infected population was $1.6 \%$ for anti-HBsAg antibodies and $16.1 \%$ for anti-HCV antibodies. These rates were lower than the $6 \%$ rate for anti-HBsAg antibody co-infection and the $31 \%$ rate for anti-HCV antibody 
TABLE I

Seroprevalence of hepatitis B virus (HBV), hepatitis C virus (HCV) and human immunodeficiency virus (HIV) co-infection in 1,228 individuals screened at the infectology clinic of the Regional University Hospital

\begin{tabular}{|c|c|c|c|c|c|}
\hline Gender & $\begin{array}{c}\text { Prevalence } \\
\text { n (\%) }\end{array}$ & $\begin{array}{l}\text { Male } \\
\mathrm{n}(\%)\end{array}$ & $\begin{array}{c}\text { Female } \\
\text { n }(\%)\end{array}$ & Ratio & $\mathrm{p}^{a}$ \\
\hline HIV & $249(20.3)$ & $142(57.1)$ & $107(42.9)$ & $1.3: 1$ & $>0.05$ \\
\hline $\mathrm{HBV}$ & $73(5.9)$ & $43(59.0)$ & $30(41.0)$ & $1.4: 1$ & $>0.05$ \\
\hline $\mathrm{HCV}$ & $173(14.0)$ & $122(70.5)$ & $51(29.5)$ & $2.4: 1$ & $<0.05$ \\
\hline HIV/HBV & $5(0.4)$ & $4(80.0)$ & $1(20.0)$ & $4: 1$ & $>0.05$ \\
\hline $\mathrm{HIV} / \mathrm{HCV}$ & $49(4.0)$ & $37(75.5)$ & $12(24.5)$ & $3: 1$ & $<0.05$ \\
\hline $\mathrm{HBV} / \mathrm{HCV}$ & $2(0.2)$ & $1(50.0)$ & $1(50.0)$ & $1: 1$ & $>0.05$ \\
\hline HIV/HBV/HCV & $1(0.1)$ & - & $1(100.0)$ & $0: 1$ & - \\
\hline Total & 552 & 349 & 203 & - & - \\
\hline
\end{tabular}

$a$ : p comparing male/female gender.
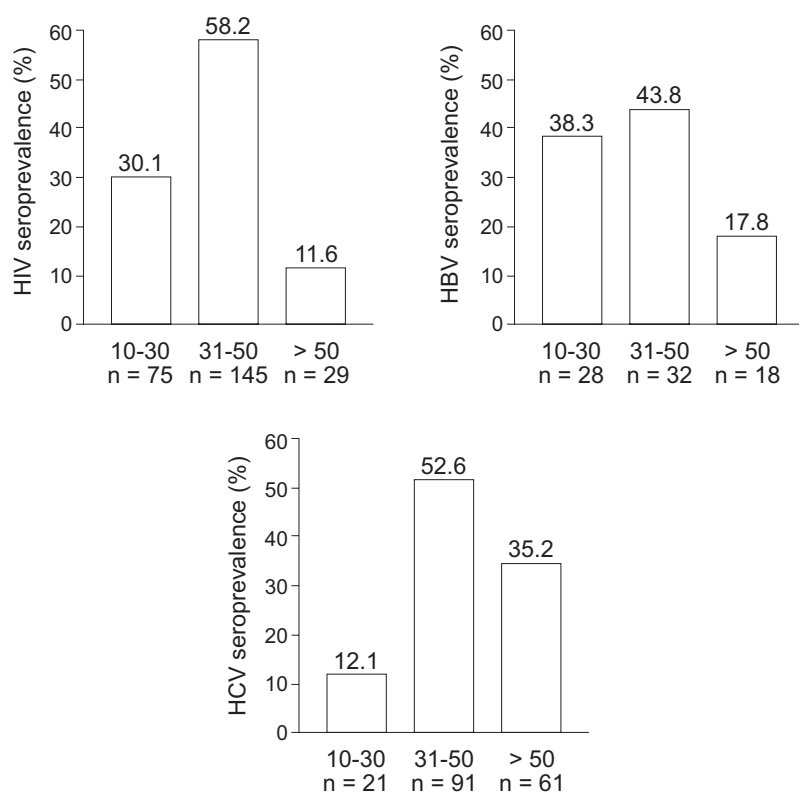

Prevalence of human immunodeficiency virus (HIV), HBsAg and hepatitis $\mathrm{C}$ virus $(\mathrm{HCV})$ antibodies in relation to age in individuals screened at the infectology clinic of the regional University Hospital. HBV: hepatitis B virus.

co-infection with HIV, which are the median results for São Paulo city and some cities from different regions of the country (Mendes-Correa et al. 2000, Segurado et al. 2004, Tovo et al. 2006). Although very few data exist on the prevalence of HIV or HIV-hepatitis virus co-infection in small and medium-sized cities (Eyer-Silva et al. 2008), it is possible that the number of intravenous injecting drug users, a key risk factor for HIV-hepatitis co-infection, is lower in our region than in large urban centres, thus explaining in part our results.

The overall seroprevalence rate for $\mathrm{HCV}$ infection was $14 \%$. Despite the importance of HCV worldwide, there are no data regarding $\mathrm{HCV}$ infection in the general population or selected individuals from the western re-

\section{TABLE II}

Prevalence of hepatitis $\mathrm{C}$ virus (HCV) genotypes in individuals screened at an infectology clinic with anti-HCV antibodies and RNA-PCR detection

\begin{tabular}{lcccc}
\hline \multicolumn{5}{c}{ Genotypes } \\
\hline & Type 1 & Type 2 & Type 3 & Mixed \\
\hline $\mathrm{n}(\%)$ & $\mathrm{n}(\%)$ & $\mathrm{n}(\%)$ & $\mathrm{n}(\%)$ & $\mathrm{n}(\%)$ \\
$1 \mathrm{a}$ & $1 \mathrm{~b}$ & $2 \mathrm{~b} / 2 \mathrm{c}$ & - & $1 \mathrm{a} / \mathrm{b}$ \\
$20(32.2)$ & $25(40.3)$ & $1(1.6)$ & $15(24.2)$ & $1(1.6)$ \\
\hline
\end{tabular}

gion of SP. In Brazil, the prevalence in the general population varies greatly from very low rates of $0.1 \%$ in the semi-arid Northeast Region (Focacia et al. 1998, Tavares-Neto et al. 2005, Figueiró-Filho et al. 2007) to higher rates in the Amazon Region of 4-6\% (Tavares-Neto et al. 2004, Silva et al. 2006, Paraná et al. 2007). The HCV seroprevalence encountered in this study was similar to those found in some populations considered to be at risk for $\mathrm{HCV}$ infection, including $15 \%$ and $11 \%$ prevalence in alcoholics and chronic renal patients undergoing hemodialysis, respectively (Galperim et al. 2006, Freitas et al. 2008). HCV infection affected males more than females and there was an increase in the prevalence of anti-HCV antibodies in individuals $>50$-years old when compared to HIV or HBV. Several possibilities could explain these results: individuals $>50$-years old are encouraged to get tested; the overall time of exposure to viral hepatitis throughout life is higher in older individuals, and screening among blood donors is a recent trend in developing countries. An age-specific increase in the prevalence of $\mathrm{HCV}$ is a worldwide trend that is also seen in Turkey, Spain, Italy, Japan and China (Alter 2007).

When HCV infection is clinically suspected in subjects considered at risk for hepatitis virus infection, positive ELISA results are used to confirm exposure to $\mathrm{HCV}$. A qualitative HCV-RNA assay should be performed to distinguish individuals with chronic infection from those 
who have spontaneously cleared the virus (Gonçales \& Gonçales-Júnior 2007). Moreover, HCV has a large genetic heterogeneity and may differ from one region to another. Genotyping is necessary to establish the optimal duration of therapy and response. Thus, HCV-RNA was tested for and detected in $73.5 \%$ of samples with a predominance of genotypes 1 and 3, which is similar to the results recently shown in large cohorts from Brazil (Campiotto et al. 2005, Silva et al. 2007).

In conclusion, a significant percentage $(44.9 \%)$ of selected individuals seen in the infectology clinic had antibodies against HBV, HCV and/or HIV that would have otherwise remained undiagnosed. These results demonstrate the key role of primary public health care centres distributed throughout Brazilian municipalities in screening subjects as well as the importance of regional reference hospitals in the diagnosis and management of populations considered to be at risk for blood-borne diseases.

\section{REFERENCES}

Alter MJ 2007. Epidemiology of hepatitis C virus infection. World $J$ Gastroenterol 13: 2436-2441.

Campiotto S, Pinho JRR, Carrilho FJ, Da Silva LC, Souto FID, Spinelli V, Pereira LMMB, Coelho HSM, Silva AO, Fonseca JC, Rosa H, Lacet CMC, Bernardini AP 2005. Geographic distribution of hepatitis C virus genotypes in Brazil. Braz J Med Biol Res 38: 41-49.

Coelho HC, Perdoná GC, Neves FR, Passos AD 2007. HIV prevalence and risk factors in a Brazilian penitentiary. Cad Saude Publica 23: 2197-2204.

Eyer-Silva WA, Couto-Fernandez JC, Silva-de-Jesus C, Morgado MG 2008. Prevalence of HIV type 1 drug resistance mutations in treatment-naïve and experienced patients from resource-limited settings with universal access to antiretroviral therapy: a survey in two small Brazilian cities. Mem Inst Oswaldo Cruz 103: 143-149.

Fialho M, Messias M, Page-Shafer K, Farre L, Schmalb M, PedralSampaio D, Ramos M, Brites C 2008. Prevalence and risk of blood-borne and sexually transmitted viral infections in incarcerated youth in Salvador, Brazil: opportunity and obligation for intervention. AIDS Behav 12: 17-24.

Figueiró-Filho EA, Senefonte FRA, Lopes AHA, Morais OO, Souza Júnior VG, Maia TL, Duarte G 2007. Freqüência das infecções pelo HIV-1, rubéola, sífilis, toxoplasmose, citomegalovírus, herpes simples, hepatite B, hepatite C, doença de Chagas e HTLV I/ II em getantes do estado de Mato Grosso do Sul. Rev Soc Bras Med Trop 40: 181-187.

Focaccia R, da Conceição OJ, Sette Júnior H, Sabino E, Bassit L, Nitrini DR, Lomar AV, Lorenço R, Vieira de Souza F, Kiffer CR, Santos EB, Gonzáles MP, Aáez-Alquézar A, Riscal JR, Fischer D 1998. Estimates prevalence of viral hepatitis in the general population of the municipality of São Paulo, measured by a serologic survey of stratified randomized and residence-based population. Braz J Infect Dis 2: 269-284.

Freitas SZ, Cunha RV, Martins RMB, Teles SA, Ilbanhes ML, Mota-Castro ARC 2008. Prevalence, genotypes and risk factors with hepatitis $\mathrm{C}$ virus infection in hemodialysis patientes in Campo Grande, MS, Brazil. Mem Inst Oswaldo Cruz 103: 405-408.

Galperim B, Cheinquer H, Stein A, Fonseca A, Lunge V, Ikuta N 2006. Prevalence of hepatitis $C$ virus in alcoholis patients: role of parenteral risk factors. Arq Gastroenterol 43: 71-72.
Gonçales NSL, Gonçales Júnior FL 2007. Laboratory testing for hepatitis C. Braz J Infect Dis 11: 22-24.

Kallings LO 2008. The first postmodern pandemic: 25 years of HIV/ AIDS. J Intern Med 263: 218-243.

Lazarus JV, Shete PB, Eramova I, Merkinaite S, Matic S 2007. HIV/ hepatitis co-infectionn in Eastern Europe and new pan-European approaches to hepatitis prevention and management. Int J Drug Policy 18: 426-432.

Loewenson R 2007. Exploring equity and inclusion in the responses to AIDS. AIDS Care 19: 2-11.

Mendes-Corrêa MC, Barone AA, Cavalheiro NP, Tengan FM, Guastini C 2000. Prevalence of hepatitis B and C in the sera of patients with HIV infection in São Paulo, Brazil. Rev Inst Med Trop S Paulo 42: 81-85.

Oliveira ML, Yoshida CF, Telles PR, Hacker MA, Oliveira SA, Miguel JC, do O KM, Bastos FI 2009. Trends in HCV prevalence, risk factors and distribution of viral genotypes in injecting drug users: findings from two cross-sectional studies. Epidemiol Infect 137: 970-979.

Paraná R, Paiva T, Leite MR, Oliveira FN, Kali N, Lobato C, Dantas $\mathrm{T}$, Tavares-Neto J 2007. Infection with hepatitis C virus among health care workers in the Brazilian western Amazon Region (Rio Branco, state of Acre). Am J Trop Med Hyg 6: 165-169.

Pechansky F, Woody G, Inciardi J, Surratt H, Kessler F, Von Diemen L, Bumaguin DB 2006. HIV seroprevalence among drug users: an analysis of selected variables based on 10 years of data collection in Porto Alegre, Brazil. Drug Alcohol Depend 82: 109-113.

Segurado AC, Braga P, Etzel A, Cardoso MR 2004. Hepatitis C virus co-infectionn in a cohort of HIV-infected individuals from Santos, Brazil: seroprevalence and associated factors. AIDS Patients Care STDS 18: 135-143.

Silva CMD, Costi C, Krug LP, Ramos AB, Grandi T, Gandolfi VL, Menezes ME, Ocampos M, Niel C, Rossetti MLR 2007. High proportion of hepatitis $\mathrm{C}$ virus genotypes 1 and 3 in a large cohort of patients from Southern Brazil. Mem Inst Oswaldo Cruz 102: 867-870.

Silva LK, Silva MBS, Rodart IF, Lopes GB, Costa FQ, Melo ME, Gusmão E, Reis MG 2006. Prevalence of hepatitis C virus (HCV) infection and HCV genotypes of hemodialysis patientes in Salvador, Northeastern Brazil. Braz J Med Biol Res 39: 595-602.

Soriano V, Barreiro P, Nuñez M 2006. Management of chronic hepatitis B and C in HIV-coinfected patients. J Antimicrob Chemother 57: 815-818.

Tavares-Neto J, Almeida D, Soares MC, Uchoa R, Viana S, Darub R, Farias E, Rocha G, Vitvitski L, Paraná R 2004. Seroprevalence of hepatitis B and C in the western Brazilian Amazon Region (Rio Branco, Acre): a pilot study carried out during a hepatitis B vaccination program. Braz J Infect Dis 8: 133-139.

Tavares-Neto J, Prata A, Paraná R, Valente VB, Vitvitski L, Figueiredo JFC 2005. Very low prevalence of hepatitis $C$ virus infection in rural communities of Northeastern Brazil with a high prevalence of schistosomiasis mansoni. Rev Soc Bras Med Trop 38: 290-293.

Tovo CV, Santos DE, Mattos AZ, Almeida PRL, Mattos AA, Santos BR 2006. Ambulatorial prevalence of hepatitis B and C markers in patients with human immunodeficiency virus infection in a general hospital. Arq Gastroenterol 43: 73-76.

UNAIDS 2008. Report on the Global AIDS epidemic. Available from: www.unaids.org [updated Jan 2009; cited 01 Mar 2009].

Wools-Kaloustian K, Kimaiyo S 2006. Extending HIV care in resource-limited settings. Curr HIV/AIDS Rep 3: 182-186. 